a proposal for research they're not interested in performing. They could instead write a piece on their research targeted at a non-expert audience, for example. Similarly, those planning to enter industry could pitch a new product, and those aiming to become lecturers could participate in and report on a teaching internship. Choosing a career track with corresponding requirements could become as standard as selecting an inorganic, organic, physical or biological chemistry tracks.

The events hosted and sponsored by science departments are an area in which graduate school could become more inclusive and beneficial to students pursuing careers beyond academia. There are many professionals in industry and non-conventional fields who could occupy some slots on the department calendar. Furthermore, by promoting external programmes aimed at non-academic-career preparation, science departments could ensure that students are aware of such opportunities and display public support for their participation.

\section{MINDSET SHIFT}

To successfully implement these changes, we must first subvert the assumption on which $\mathrm{PhD}$ programmes seem to be built: that their participants plan to pursue academia. This mindset is in part a consequence of $\mathrm{PhD}$ programmes being crafted by professors who used their own career trajectory as a template.

But I suspect it's also a product of the unfortunate reality that $\mathrm{PhD}$ advisers simply do not view non-academic careers with the same degree of admiration. The fact that multiple people have written articles on how to break the apparently devastating news to your adviser that you aren't following in their footsteps speaks volumes. If academia can't appreciate the inherent value of professions beyond 'research professor', then maybe it can at least recognize the benefits it gains from having $\mathrm{PhD}$ trained scientists in roles outside academia.

For example, science communicators create crucial dialogue between scientists and the public, helping to establish a wider audience for researchers' work and prevent misinterpretation of findings. Those in the field of science policy help to inform important regulations that affect national agencies funding academic research. Highschool science teachers, lecturers and lab instructors are training the next generation of graduate students who will work in university labs. Hopefully, the $\mathrm{PhD}$ programmes that these students experience help them to feel validated in and prepared for whatever career path they choose.

Sarah Anderson is a PhD candidate in the chemistry department at Northwestern University in Evanston, Illinois.

Q\&A

\title{
Developing cancer drugs from African plants
}

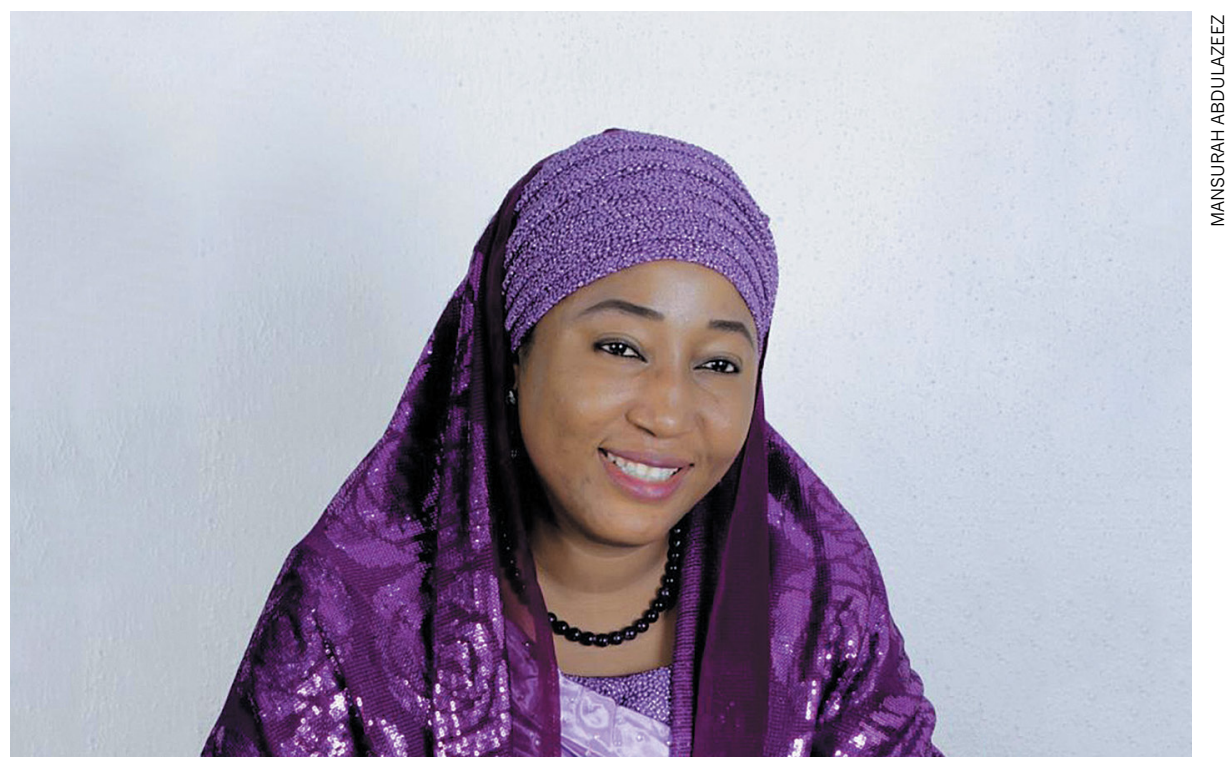

Mansurah Abdulazeez is a molecular biologist at the Center for Biotechnology Research, Bayero University Kano, Nigeria. Her research aims to identify potent anticancer agents in African plants. Last November, the government of Spain awarded her their Science by Women Fellowship. And in June, she won a Nigerian National Research Grant of 31 million naira (US \$86,000) from the Tertiary Education Trust Fund. Nature asked Abdulazeez about her life and research.

\section{What can you tell us about your scientific background?}

Growing up, I always enjoyed science. I originally wanted to become a medical doctor, but I ended up studying biochemistry during my undergraduate studies at Ahmadu Bello University in Zaria, Nigeria. I got my master's degree, and then my $\mathrm{PhD}$ there, studying antihypertensive and anticancer activities of African plants. I was also a visiting scholar at Chiang Mai University in Thailand for six months as part of my PhD research.

\section{What does your research focus on?}

My research is aimed at identifying potent, safe and effective anticancer agents from Nigerian plants. We have screened and confirmed the cytotoxic activities of extracts of the drumstick (Moringa oleifera) and soursop (Annona muricata) trees as well as the native Nigerian shrub Peristrophe bicalyculata on cervical carcinoma and fetal lung carcinoma cell lines.
We also studied what anticancer mechanisms these plants exhibit. We found that these plants act in the body through a variety of mechanisms - there is no single mode of action for all plants (A. A. Mansurah et al. Rom. Biotechnol. Lett. 18, 7995-8006; (2013).

\section{Why is the study of African plants important} for cancer research?

It is well documented that these plants have an enormous, largely unstudied anticancer potential (V. Kuete \& T. Efferth Biomed. Res. Int. 2015, 914813; 2015). Research into herbs such as Guiera senegalensis, which is used by traditional African healers and known as 'Sabara' by locals, has led to the discovery of several anticancer drugs. In my view, this demonstrates how the study of African plants can result in the development of valuable drugs.

\section{What is your advice to young African women} who want to pursue science?

Participate in local and international conferences that are relevant to your fields of study, so as to keep yourself updated on cutting-edge research tools, methodologies and funding opportunities. Always ask for support from senior colleagues - and family members - whenever you need it. Remain focused, tenacious and hard working.

\section{INTERVIEW BY ABDULLAHI TSANN I}

This interview has been edited for length and clarity. 